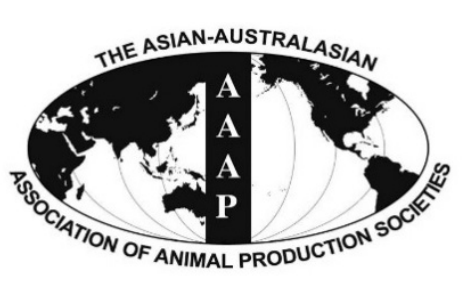

Open Access

Asian Australas. J. Anim. Sci.

Vol. 28, No. 9 : 1317-1326 September 2015

http://dx.doi.org/10.5713/ajas.14.0915

www.ajas.info

pISSN 1011-2367 elSSN 1976-5517

\title{
Energy Value of Cassava Products in Broiler Chicken Diets with or without Enzyme Supplementation
}

\author{
M. M. Bhuiyan and P. A. Iji* \\ School of Environmental and Rural Science, University of New England, Armidale, NSW 2351, Australia
}

\begin{abstract}
This study investigated the metabolizable energy (ME) intake, net energy of production (NEp), heat production (HP), efficiencies of ME use for energy, lipid and protein retention as well as the performance of broiler chickens fed diets based on cassava chips or pellets with or without supplementation with an enzyme product containing xylanase, amylase, protease and phytase. The two products, cassava chips and pellets, were analysed for nutrient composition prior to feed formulation. The cassava chips and pellets contained $2.2 \%$ and $2.1 \%$ crude protein; $1.2 \%$ and $1.5 \%$ crude fat; and $75.1 \%$ and $67.8 \%$ starch, respectively. Lysine and methionine were $0.077 \%, 0.075 \%$, and $0.017 \%, 0.020 \%$ protein material, respectively, while calculated ME was 12.6 and $11.7 \mathrm{MJ} / \mathrm{kg}$, respectively. Feed intake to day 21 was lower $(\mathrm{p}<0.01)$ on the diet containing cassava chips compared to diets with cassava pellets. Enzyme supplementation increased $(p<0.01)$ feed intake on all diets. Live weight at day 21 was significantly $(\mathrm{p}<0.01)$ reduced on the diet based on cassava chips compared to pellets, but an improvement $(\mathrm{p}<0.01)$ was noticed with the enzyme supplementation. Metabolizable energy intake was reduced $(\mathrm{p}<0.01)$ by both cassava chips and pellets, but was increased $(\mathrm{p}<0.01)$ on all diets by enzyme supplementation. The NEp was higher $(\mathrm{p}<0.01)$ in the maize-based diets than the diets containing cassava. Enzyme supplementation improved $(\mathrm{p}<0.01) \mathrm{NEp}$ in all the diets. Heat production was highest $(\mathrm{p}<0.01)$ on diets containing cassava pellets than on cassava chips. It is possible to use cassava pellets in diets for broiler chickens at a level close to $50 \%$ of the diet to reduce cost of production, and the nutritive value of such diets can be improved through supplementation of enzyme products containing carbohydrases, protease, and phytase. (Key Words: Boiler Chicken, Cassava, Net Energy, Growth Performance)
\end{abstract}

\section{INTRODUCTION}

The world production of cassava was 262.6 million tonnes in 2012, with a steady increase in production over previous years (FAO, 2012). Thailand is the second largest producer of cassava in the world but significantly, most of its production is processed into starch or animal feed, unlike the output from African producers where cassava is an important human food. Cassava chips and pellets are the key cassava products used in animal feeding, which can replace some or all of the cereal grain in diets for poultry (Iji et al., 2011). These cassava products are also exported to Europe and other parts of the world. A study by Brum et al. (1990) showed that up to $66.7 \%$ of maize in broiler diets can be replaced by cassava meal without

\footnotetext{
* Corresponding Author: P. A. Iji. Tel: +61-2-6773-2082, Fax: +61-2-6773-3922, E-mail: piji@une.edu.au

Submitted Dec. 2, 2014; Revised Feb. 1, 2015; Accepted Mar. 5, 2015
}

compromising growth performance. Other researchers have reported variable responses of diets containing cassava products such as chips and pellets in broiler diets (Obikaonu and Udedibie, 2006). These inconsistencies may be due to differences in cultivars or product processing prior to feeding or poor digestion of the main carbohydrates in cassava.

There is a need for research on cassava and its byproducts with the aim of maximizing their energy value for broiler chickens. In particular, the utilization of energy in cassava products by poultry has not been extensively studied under controlled environments. The use of biotechnology in the form of microbial enzymes holds great potential for maximizing carbohydrate digestion and energy value of cassava products in poultry feeding. Microbial enzymes have been employed in diets containing various cereal grains (Bedford, 1996; Cowieson et al., 2006) but few investigations have been carried out in diets containing 
cassava. This is an area that needs to be investigated, in order to position cassava as an alternative source of energy in poultry diets. The current study assessed the carbohydrate digestion and energy value of cassava products in broiler chicken diets with or without microbial enzyme supplementation.

\section{MATERIALS AND METHODS}

\section{Birds and housing}

A total of 384 one-day-old male Cobb-500 broiler chicks were used in a $3 \times 2$ factorial arrangement to compare diets with two cassava products (chips and pellets) or maize, with or without a combination of exogenous feed enzymes (Avizyme 1502, with active enzymes xylanase $(600$ Units/g), protease $(8,000$ Units/g) and amylase (800 Units/g); and Phyzyme XP, a phytase feed enzyme. Both enzymes were supplied by Feedworks, Australia Pty Ltd.

Each treatment had 8 replicates, with eight chicks per replicate. The chicks were reared in floor cages in an environmentally controlled house up to day 16 . The birds were moved to apparent metabolizable energy (AME) cages in a climate-controlled room and excreta were collected for three days from 18, 19, and 20 days of age. The room temperature was initially set at $32^{\circ} \mathrm{C}$ and was gradually reduced to $25 \pm 1^{\circ} \mathrm{C}$ by 21 days. Experimental diet and drinking water were offered ad libitum to the birds. The experiment was approved by the Animal Ethics Committee of the University of New England (Approval No.: AEC09/100).

\section{Diets}

Balanced diets were formulated (Table 1) to contain the cassava products or maize as primary energy source in the diet with or without enzyme supplementation to meet NRC (1994) recommendations. The ingredients in particular whole maize grain as well as cassava chips and pellet were ground through a hammer mill before mixing. All experimental diets were iso-caloric and iso-nitrogenous; relevant diets were supplemented with exogenous enzymes (Avizyme 1502, $0.5 \mathrm{~g}$ and Phyzyme XP, $0.1 \mathrm{~g}$ per $\mathrm{kg}$ of each diet) and all diets were further pelleted using a cold pelleting process. Each diet was incorporated with titanium dioxide $\left(\mathrm{TiO}_{2}\right)$ at a rate of $0.05 \%$ as an indigestible marker to enable measurement of nutrient digestibility as well as for AME.

\section{Data collection}

Feed leftover and body weights (BW) were recorded on days 7,14 and 21 for the determination of average feed intake (FI), BW, and feed conversion ratio (FCR) on a floor cage (replicate) basis. On day 7 and 21, one or three birds (respectively) from each cage were randomly selected,
Table 1. Ingredient and nutrient composition of the diet

\begin{tabular}{|c|c|c|c|}
\hline \multirow[b]{2}{*}{ Items } & \multicolumn{3}{|c|}{ Starter ( 0 to $21 \mathrm{~d})$, fed basis $(\%)$} \\
\hline & $\begin{array}{l}\text { Control } \\
\text { (maize) }\end{array}$ & $\begin{array}{c}\text { Cassava } \\
\text { chips }\end{array}$ & $\begin{array}{c}\text { Cassava } \\
\text { pellet }\end{array}$ \\
\hline \multicolumn{4}{|l|}{ Ingredients } \\
\hline Maize & 58.7 & - & - \\
\hline Cassava chip & - & 51.0 & - \\
\hline Cassava pellet & - & - & 50.5 \\
\hline Soybean meal & 34.5 & 40.1 & 40.6 \\
\hline Choline chloride $70 \%$ & 0.10 & 0.10 & 0.10 \\
\hline Sodium bicarbonate & 0.10 & 0.10 & 0.10 \\
\hline Fat/oil & 3.10 & 5.00 & 5.10 \\
\hline Limestone & 1.30 & 1.30 & 1.30 \\
\hline DCP & 1.80 & 1.70 & 1.60 \\
\hline Salt & 0.30 & 0.30 & 0.30 \\
\hline Lysine & 0.08 & 0.08 & 0.09 \\
\hline DL methionine & 0.19 & 0.19 & 0.17 \\
\hline $\operatorname{Premix}^{1}$ & 0.20 & 0.20 & 0.20 \\
\hline Titanium dioxide & 0.05 & 0.05 & 0.05 \\
\hline \multicolumn{4}{|l|}{ Nutrient composition (\%) } \\
\hline $\mathrm{ME}(\mathrm{MJ} / \mathrm{kg})$ & 12.77 & 12.77 & 12.78 \\
\hline $\mathrm{CP}$ & 21.1 & 21.1 & 21.2 \\
\hline Lysine & 1.51 & 1.50 & 1.52 \\
\hline Methionine & 0.54 & 0.56 & 0.56 \\
\hline Threonine & 0.89 & 0.95 & 0.94 \\
\hline Calcium & 1.1 & 1.4 & 1.1 \\
\hline Available Phos. & 4.3 & 4.2 & 4.4 \\
\hline
\end{tabular}

DCP, dicalcium phosphate; ME, metabolizable energy; $\mathrm{CP}$, crude protein. ${ }^{1}$ Supplied per $\mathrm{kg}$ of diet (mg): vitamin A (as all-trans retinol), $3.6 \mathrm{mg}$; cholecalciferol, $0.09 \mathrm{mg}$; vitamin $\mathrm{E}$ (as d- $\alpha$-tocopherol), $44.7 \mathrm{mg}$; vitamin $\mathrm{K}_{3}, 2 \mathrm{mg}$; thiamine, $2 \mathrm{mg}$; riboflavin, $6 \mathrm{mg}$; pyridoxine hydrochloride, $5 \mathrm{mg}$; vitamin $\mathrm{B}_{12}, 0.2 \mathrm{mg}$; biotin, $0.1 \mathrm{mg}$; niacin, $50 \mathrm{mg}$; D-calcium pantothenate, $12 \mathrm{mg}$; folic acid, $2 \mathrm{mg}$; $\mathrm{Mn}, 80 \mathrm{mg}$; Fe, $60 \mathrm{mg}$; $\mathrm{Cu}, 8 \mathrm{mg}$; I, 1mg; Co, $0.3 \mathrm{mg}$; and Mo, $1 \mathrm{mg}$.

weighed and euthanized by cervical dislocation. Weights of the small intestine, proventriculus and gizzard with content, liver, pancreas, spleen and bursa of Fabricius were recorded. Ileal digesta (from Meckel's diverticulum to the ileo-caecal junction) were collected on day 21 and pooled by replicate. Digesta were stored at $-20^{\circ} \mathrm{C}$ prior to freeze-drying and ground through a small coffee grinder for analyses of starch, gross energy (GE) and crude protein (CP).

\section{Preparation of carcass samples}

At 21 day, two birds per replicate were killed and the whole intact body was frozen immediately and later processed. Both chicks from the same cage were processed together. After chopping and coarse-grinding individual chickens, they were thoroughly mixed and two subsamples (around $250 \mathrm{~g}$ each, wet weight) were taken, finely ground and freeze-dried as described by Olukosi et al. (2008). The two subsamples were mixed together after drying and ground again. Hence chemical analysis was on one sample from each cage and not from individual chickens. 
The AME was measured using the marker $\left(\mathrm{TiO}_{2}\right)$-based faecal collection method on samples collected between 18 and 21 days of age. The representative excreta sample was collected from each cage over three days, pooled and mixed thoroughly, subsample, freeze-dried, and analysed for the marker and GE.

\section{Chemical analysis}

Excreta, diet and ileal digesta samples were analysed for GE with the purpose of determining the metabolizable energy (ME). The ME content of cassava chips and pellets were calculated according to the equation $(\mathrm{ME}[\mathrm{kcal} / \mathrm{kg}]=$ $53+38 \times[\% \mathrm{CP}+2.25 \times \%$ ether extractable fat $\{\mathrm{EE}\}+1.1 \times \%$ Starch $+\%$ Sugar]) developed by Carpenter and Clegg (1956). Samples were dried at $105^{\circ} \mathrm{C}$ in a drying oven for $24 \mathrm{~h}$ for DM determination. Gross energy was determined in a bomb calorimeter (IKA - WERKE bomb calorimeter [C7000, GMBH \& CO., Staufen, Germany]) using benzoic acid as a calibration standard. The nitrogen content of the diets, ground carcass and ileal content were determined according to the Dumas combustion technique as described by Sweeney (1989) using a LECO FP-2000 automatic nitrogen analyser (Leco FP analyser model 602600; Leco Corp., St Joseph, MI, USA) with ethylenediaminetetraacetic acid as a calibration standard. The $\mathrm{CP}$ equivalent of the ingredients was calculated as $\mathrm{N}(\%) \times 6.25$. The starch and resistant starch contents of the maize samples were determined using the Megazyme total starch kit (AMG/AA 05/2006) based on the method developed by McCleary et al. (1994). The amylose/amylopectin ratio was determined with a Megazyme amylose/amylopectin assay kit (Megazyme International Ireland, Bray Business Park, Bray, Ireland) using the selective quantitative precipitation reaction of con-canavalin A (Con A) for amylopectin (Gibson et al., 1997) and by the colorimetric method of iodine binding for amylose (Chrastil, 1987). Insoluble and soluble non-starch polysaccharides (NSPs) were analyzed by gas chromatography (VARIAN, CP-3800, Walnut Creek, CA, USA) as the alditol acetate derivatives of monosaccharide based on the method developed by Englyst and Hudson (1993), and Theander and Westerlund (1993).

Minerals were analysed by inductively coupled plasma method (Vista MPX-radial) following the protocol of Anderson and Henderson (1986). Concentrations of amino acids were determined using pre-column derivatisation amino acid analysis with 6-aminoquinolyl-Nhydroxysuccinimidyl carbamate followed by separation of the derivatives and quantification by reversed phase high performance liquid chromatography according to Cohen and Michaud (1993) and Cohen (2001).

Titanium dioxide concentrations in the diets, ileal digesta and excreta samples were measured after ashing the samples and treating the ash with boiling 7.4 M Sulphuric acid according to the method of Short et al. (1996). The concentrations of the $\mathrm{TiO}_{2}$ marker and of nutrients in the feed and ileal digesta were used to calculate the digestibility coefficient of protein, GE, and starch, using the following equation:

$$
\begin{aligned}
& \text { Digestibility coefficient } \\
& =1-\frac{\text { Digesta nutrient }(\mathrm{g} / \mathrm{kg}) / \text { Digesta } \mathrm{TiO}_{2}(\mathrm{~g} / \mathrm{kg})}{\text { Diet nutrient }(\mathrm{g} / \mathrm{kg}) / \text { Diet } \mathrm{TiO}_{2}(\mathrm{~g} / \mathrm{kg})}
\end{aligned}
$$

The ground carcass samples were analysed for GE, diethyl EE and nitrogen $(\mathrm{N})$. The data were used to calculate AME, nutrient retention, net energy of production net energy of production (Nep), heat production (HP) and efficiencies of utilization of metabolizable energy for protein, fat and energy retention as described by Olukosi et al. (2008). All laboratory samples were analysed in duplicate.

\section{Calculations}

$\operatorname{AME}(\mathrm{MJ} / \mathrm{kg})$ was calculated as follows:

$$
\mathrm{AME}=\mathrm{GE}_{\mathrm{i}}-\left[\mathrm{GE}_{\mathrm{o}} \times\left(\mathrm{T}_{\mathrm{i}} / \mathrm{T}_{\mathrm{o}}\right)\right]
$$

Where $\mathrm{GE}_{\mathrm{i}}$ is gross energy $(\mathrm{MJ} / \mathrm{kg})$ in feed; $\mathrm{GE}_{\mathrm{o}}$ is the gross energy $(\mathrm{MJ} / \mathrm{kg})$ in excreta, $\mathrm{T}_{\mathrm{i}}$ is the concentration of titanium in the diets and $T_{o}$ is the concentration of titanium in the excreta.

NEp was calculated as follows:

$$
\begin{aligned}
& \text { Initial GE of carcass }(\mathrm{kJ}) \\
& =\text { Carcass GE }(\mathrm{kJ} / \mathrm{g}) \times \mathrm{BW} \text { of bird }(\mathrm{g})
\end{aligned}
$$

Final GE content of carcass $(\mathrm{kJ})$

$=$ Carcass $\mathrm{Ge}(\mathrm{kJ} / \mathrm{g}) \times \mathrm{BW}$ of bird $(\mathrm{g})$

$$
\operatorname{NEp}(k J)=(2)-(1)
$$

The HP, which consists of the heat increment of feeding and fasting HP was calculated as the difference between NEp and ME intake by this equation:

$\mathrm{HP}(\mathrm{kJ})=\mathrm{MEI}-\mathrm{NEp}$, where ME intake (MEI) was calculated using the following formula:

$$
\operatorname{MEI}(\mathrm{kJ})=\operatorname{ME}(\mathrm{kJ} / \mathrm{g}) \times \mathrm{FI}(\mathrm{g})
$$

Energy retained as fat $\left(\mathrm{RE}_{\mathrm{f}}\right)$ and as protein $\left(\mathrm{RE}_{\mathrm{p}}\right)$ was calculated as follows:

$$
\begin{aligned}
& \mathrm{RE}_{\mathrm{f}}(\mathrm{kJ})=\text { Carcass fat }(\mathrm{g}) \times 38.2 \mathrm{~kJ} / \mathrm{g} \\
& \mathrm{RE}_{\mathrm{p}}(\mathrm{kJ})=\text { Carcass crude protein content }(\mathrm{g}) \times 23.6 \mathrm{~kJ} / \mathrm{g}
\end{aligned}
$$


The values 38.2 and $23.6 \mathrm{~kJ} / \mathrm{g}$ are energy values per gram of fat and protein, respectively, and were according to Larbier and Leclercq (1992).

Because excreta was collected for the last 3 days and the ME intake for killed chicken at day 21 was calculated using FI for days 0 to 21 .

Efficiency of ME use for energy retention $\left(K_{\mathrm{RE}}\right)$

$=\mathrm{NEp} / \mathrm{MEI}$

Efficiency of ME use for lipid retention $\left(K_{\mathrm{REf}}\right)$ $=\mathrm{RE}_{\mathrm{f}} / \mathrm{MEI}$

Efficiency of ME use for protein retention $\left(K_{\mathrm{REp}}\right)$ $=\mathrm{REp} / \mathrm{MEI}$

\section{Statistical analysis}

Data for each day of sampling were analysed separately. The performance data such as FI, BW, FCR, relative weight of visceral organs, nutrient digestibility and parts yield characteristic were analysed using the general linear models procedure of SPSS options, Version 18.0.0 (SPSS Inc, 2010)

Table 2. Analyzed composition of cassava products (DM basis, \%)

\begin{tabular}{|c|c|c|}
\hline Items & Cassava chips & Cassava pellets \\
\hline \multicolumn{3}{|l|}{ Nutrients } \\
\hline Dry matter & 88.6 & 89.9 \\
\hline Crude protein & 2.2 & 2.1 \\
\hline $\mathrm{ME}(\mathrm{MJ} / \mathrm{kg})$ & 12.6 & 11.7 \\
\hline Crude fat & 1.2 & 1.5 \\
\hline Total starch & 75.1 & 67.8 \\
\hline Resistant starch & 39.7 & 31.1 \\
\hline Amylose & 17.3 & 17.9 \\
\hline Amylopectin & 57.8 & 49.8 \\
\hline Total insoluble NSP & 3.9 & 5.4 \\
\hline Total soluble NSP & 0.78 & 0.83 \\
\hline \multicolumn{3}{|l|}{ Minerals } \\
\hline Calcium & 0.28 & 0.29 \\
\hline Phosphorus & 0.07 & 0.07 \\
\hline Potassium & 0.71 & 0.55 \\
\hline Iron & 0.02 & 0.06 \\
\hline Magnesium & 0.07 & 0.09 \\
\hline \multicolumn{3}{|l|}{ Amino acids } \\
\hline Lysine & 0.077 & 0.075 \\
\hline Methionine & 0.017 & 0.020 \\
\hline Threonine & 0.058 & 0.066 \\
\hline Arginine & 0.080 & 0.085 \\
\hline Histidine & 0.027 & 0.029 \\
\hline Tyrosine & 0.031 & 0.034 \\
\hline Alanine & 0.114 & 0.112 \\
\hline Glycine & 0.062 & 0.073 \\
\hline
\end{tabular}

DM, dry matter; ME, metabolizable energy; NSP, non-starch polysaccharides. for the main effects of diets, and enzyme effects with their interactions. Separation of means within a significant effect was done by Duncan's multiple range test through post hoc procedure of SPSS. Significance levels were set at $\mathrm{p} \leq 0.05$ unless otherwise specified.

\section{RESULTS}

\section{Nutrient composition of cassava products}

The chemical composition of the cassava chips and cassava pellets is presented in Table 2. The crude protein, $\mathrm{ME}$, total starch, resistant starch and amylopectin contents were higher in cassava chips than in cassava pellets $(2.2 \%$, $12.6 \mathrm{MJ} / \mathrm{kg}, 75.1 \%, 39.7 \%$, and $57.8 \%$ vs $2.1 \%, 11.7 \mathrm{MJ} / \mathrm{kg}$, $67.8 \%, 31.1 \%$ and $49.8 \%$, respectively). On the other hand, the crude fat, amylose, total insoluble and soluble NSPs contents were higher in cassava pellets than in the chips $(1.5 \%, 17.9 \%, 5.4 \%$, and $0.83 \%$ vs $1.2 \%, 17.3 \%, 3.9 \%$, and $0.78 \%$, respectively). The concentrations of $\mathrm{Ca}$ and phosphorus were similar in the two products. However, potassium was higher in cassava chips than in pellets $(0.71 \%$ vs $0.55 \%)$. The lysine and alanine contents were slightly higher in cassava chips than in cassava pellets

Table 3. Feed intake, body weight, and FCR of broiler chickens at 7 days of age given diets based on maize or cassava products with or without microbial enzymes ${ }^{1}$

\begin{tabular}{|c|c|c|c|c|}
\hline Treatments & Enzyme & $\begin{array}{c}\text { FI } \\
\text { (g/bird) }\end{array}$ & $\begin{array}{c}\text { BW } \\
\text { (g/bird) }\end{array}$ & $\begin{array}{l}\text { FCR } \\
(\mathrm{g}: \mathrm{g})\end{array}$ \\
\hline \multicolumn{5}{|l|}{ Ingredient } \\
\hline \multirow[t]{2}{*}{ Maize (control) } & - & $137.9^{\mathrm{b}}$ & $154.3^{\mathrm{bc}}$ & $1.28^{\mathrm{d}}$ \\
\hline & + & $154.4^{\mathrm{a}}$ & $175.9^{\mathrm{a}}$ & $1.19^{\mathrm{d}}$ \\
\hline \multirow[t]{2}{*}{ Cassava chips } & - & $120.6^{\mathrm{c}}$ & $116.9^{\mathrm{e}}$ & $1.73^{\mathrm{a}}$ \\
\hline & + & $138.8^{\mathrm{b}}$ & $131.8^{\mathrm{d}}$ & $1.64^{\mathrm{ab}}$ \\
\hline \multirow[t]{2}{*}{ Cassava pellets } & - & $149.3^{\mathrm{ab}}$ & $145.7^{\mathrm{c}}$ & $1.51^{\mathrm{bc}}$ \\
\hline & + & $159.8^{\mathrm{a}}$ & $156.8^{\mathrm{b}}$ & $1.46^{\mathrm{c}}$ \\
\hline \multicolumn{5}{|l|}{ Effect of ingredient } \\
\hline Maize (control) & & $146.1^{\mathrm{b}}$ & $165.2^{\mathrm{a}}$ & $1.24^{\mathrm{c}}$ \\
\hline Cassava chips & & $130.1^{\mathrm{c}}$ & $124.4^{\mathrm{c}}$ & $1.69^{\mathrm{a}}$ \\
\hline Cassava pellets & & $154.5^{\mathrm{a}}$ & $151.3^{\mathrm{b}}$ & $1.48^{\mathrm{b}}$ \\
\hline \multicolumn{5}{|l|}{ Effect of enzyme } \\
\hline- & & $135.9^{b}$ & $139.1^{\mathrm{b}}$ & $1.51^{\mathrm{a}}$ \\
\hline+ & & $151.0^{\mathrm{a}}$ & $154.9^{\mathrm{a}}$ & $1.43^{\mathrm{b}}$ \\
\hline Polled SEM & & 2.45 & 3.00 & 0.03 \\
\hline Model P & & $<0.01$ & $<0.01$ & $<0.01$ \\
\hline \multicolumn{5}{|l|}{ Source of variation } \\
\hline Ingredient & & $<0.01$ & $<0.01$ & $<0.01$ \\
\hline Enzyme & & $<0.01$ & $<0.01$ & $<0.05$ \\
\hline Ingredient $\times$ enzym & & 0.61 & 0.24 & 0.93 \\
\hline
\end{tabular}

FI, feed intake; BW, body weight; FCR, feed conversion ratio; SEM, standard error of mean.

${ }^{1}$ Each value represents the mean of 8 replicates for each treatment group. a,b,c,d,e Values with unlike superscripts within each column are significantly different $(\mathrm{p}<0.05)$ 
( $0.077 \%$ and $0.114 \%$ vs $0.075 \%$ and $0.112 \%$, respectively). Conversely, cassava pellets were higher than chips in the other amino acids such as methionine, threonine, arginine, histidine, tyrosine and glycine.

\section{Feed intake, body weight gain, and feed efficiency}

Birds fed on the diets containing cassava chips significantly $(p<0.01)$ ate less than those fed on the diets containing maize or cassava pellets up to 7 days of age (Table 3). The enzyme supplements increased $(\mathrm{p}<0.01)$ FI on all the diets; and birds fed on diets containing cassava pellets had increased FI compared to birds fed diets with cassava chips or maize. Similarly, BW at day 7 was significantly reduced $(\mathrm{p}<0.01)$ on the diet based on cassava chips but increased $(p<0.01)$ by diets with enzyme supplementation. Subsequently, there was a significantly poorer $(p<0.01)$ FCR in groups with cassava chips compared to the maize based control diet. However, the FCR of birds improved $(\mathrm{p}<0.05)$ on all diets with microbial enzyme supplementation compared to unsupplemented diets. Feed intake up to day 21 was lower $(p<0.01)$ on the diet containing cassava chips than on diets with maize or cassava pellets (Table 4). The enzyme supplements

Table 4. Feed intake, body weight and FCR of broiler chicken at 21 day of age on diets based on cassava products with or without microbial enzymes ${ }^{1}$

\begin{tabular}{|c|c|c|c|c|}
\hline Treatments & Enzyme & $\begin{array}{c}\text { FI } \\
\text { (g/bird) }\end{array}$ & $\begin{array}{c}\text { BW } \\
\text { (g/bird) }\end{array}$ & $\begin{array}{l}\text { FCR } \\
\text { (g:g) }\end{array}$ \\
\hline \multicolumn{5}{|l|}{ Ingredient } \\
\hline \multirow[t]{2}{*}{ Maize (control) } & - & $948.5^{\mathrm{bc}}$ & $696.1^{\mathrm{b}}$ & $1.46^{\mathrm{d}}$ \\
\hline & + & $1,199.7^{\mathrm{a}}$ & $881.7^{\mathrm{a}}$ & $1.44^{\mathrm{d}}$ \\
\hline \multirow[t]{2}{*}{ Cassava chips } & - & $754.9^{\mathrm{d}}$ & $453.5^{\mathrm{e}}$ & $1.86^{\mathrm{a}}$ \\
\hline & + & $940.1^{\mathrm{c}}$ & $574.6^{\mathrm{d}}$ & $1.79^{\mathrm{ab}}$ \\
\hline \multirow[t]{2}{*}{ Cassava pellets } & - & $1,006.4^{\mathrm{b}}$ & $637.1^{\mathrm{c}}$ & $1.71^{b c}$ \\
\hline & + & $1,162.5^{\mathrm{a}}$ & $749.4^{\mathrm{b}}$ & $1.67^{\mathrm{c}}$ \\
\hline \multicolumn{5}{|l|}{ Effect of ingredient } \\
\hline Maize (control) & & $1,074.1^{\mathrm{a}}$ & $788.9^{\mathrm{a}}$ & $1.45^{\mathrm{c}}$ \\
\hline Cassava chips & & $847.5^{\mathrm{b}}$ & $514.1^{\mathrm{c}}$ & $1.82^{\mathrm{a}}$ \\
\hline Cassava pellets & & $1,084.5^{\mathrm{a}}$ & $693.2^{\mathrm{b}}$ & $1.69^{\mathrm{b}}$ \\
\hline \multicolumn{5}{|l|}{ Effect of enzyme } \\
\hline - & & $903.3^{\mathrm{b}}$ & $595.6^{\mathrm{b}}$ & 1.68 \\
\hline+ & & $1,100.8^{\mathrm{a}}$ & $735.2^{\mathrm{a}}$ & 1.63 \\
\hline Pooled SEM & & 23.136 & 21.100 & 0.026 \\
\hline Model P & & $<0.001$ & $<0.001$ & $<0.001$ \\
\hline \multicolumn{5}{|l|}{ Source of variation } \\
\hline Ingredient & & $<0.01$ & $<0.01$ & $<0.01$ \\
\hline Enzyme & & $<0.01$ & $<0.01$ & 0.08 \\
\hline Ingredient $\times$ enzyme & & 0.08 & 0.15 & 0.74 \\
\hline
\end{tabular}

FI, feed intake; BW, body weight; FCR, feed conversion ratio; SEM, standard error of mean.

${ }^{1}$ Each value represents the mean of 8 replicates for each treatment group. a,b,c,d,e Values with unlike superscripts within each column are significantly different at $(\mathrm{p}<0.05)$. improved $(\mathrm{p}<0.01)$ the FI of birds on all the diets. Body weight at day 21 was also significantly reduced $(p<0.01)$ on the diet based on cassava chips, and improved $(p<0.01)$ by the enzyme supplements. There was a significantly poorer $(\mathrm{p}<0.01)$ FCR in groups with the cassava products compared to the maize-based diet, but this tended $(\mathrm{p}=0.08)$ to be improved by enzyme supplementation. There was an increase in BW with the inclusion of enzymes in all diets.

\section{Visceral organ weight}

At day 7, the relative weight of the small intestine was significantly $(\mathrm{p}<0.01)$ lower on the diet containing maize; and the highest relative weight was observed in chickens fed diets based on cassava pellets (Table 5). Irrespective of energy source, there was no significant change in the relative weight of small intestine of birds with or without enzyme supplementation. The relative weight of gizzard was significantly $(p<0.01)$ lower in chicks on the diets containing cassava pellets than on diets cassava chips at 7 days of age. However, this tended $(p=0.08)$ to be reversed by enzyme supplementation. There were no significant changes in the relative weight of liver, pancreas, spleen, bursa of Fabricius and yolk sac due to diet or enzyme supplementation.

At day 21, the relative weight of the small intestine was significantly $(\mathrm{p}<0.01)$ lower on the diet containing maize and the highest relative weight was observed in chickens fed on diets based on cassava pellets (Table 6). There was a significant $(p<0.05)$ increase in the relative weight of the small intestine in chickens fed diets without supplemented compared to enzyme supplemented diets. The interaction between cassava product/maize and enzyme supplementation on the relative weight of the small intestine was significant $(\mathrm{p}=0.037)$; with the lowest relative weight in the enzyme-supplemented maize-based diet. The relative weight of gizzard was significantly $(p<0.001)$ lower on the diets containing cassava pellets than on diets with maize or cassava chips at this age. However, the effect of enzyme supplement was absent on the weight of this organ at $21 \mathrm{~d}$.

The relative weight of the proventriculus was not changed by either cassava product. The interaction between diet and enzyme supplement was significant on the relative weight of proventriculus; it was significantly $(p<0.01)$ lower in birds fed the diet containing cassava pellet with enzyme supplementation than in those without enzyme supplement. The relative weight of liver was lower $(\mathrm{p}<0.01)$ on the diet containing maize than on the diets containing cassava pellets. However, the interaction between diet and enzyme was significant $(\mathrm{p}<0.01)$ on the relative weight of liver and pancreas. There were no significant changes in the relative weight of spleen and bursa Fabricius. 
Table 5. Relative weight of visceral organs ( $\mathrm{g} / 100 \mathrm{~g}$ of body weight) of broiler chickens at 7 days of age fed diets based on maize or cassava products, with or without microbial enzymes ${ }^{1}$

\begin{tabular}{|c|c|c|c|c|c|c|c|c|c|}
\hline Treatments & Enzyme & Small intes ${ }^{2}$ & Gizzard $^{2}$ & Provent $^{2}$ & Liver & Pancreas & Spleen & Bursa & Yolk sac \\
\hline \multicolumn{10}{|l|}{ Ingredient } \\
\hline \multirow[t]{2}{*}{ Maize (control) } & - & $9.11^{\mathrm{ab}}$ & $6.14^{\mathrm{bc}}$ & 0.91 & 4.91 & 0.42 & 0.08 & 0.16 & 0.15 \\
\hline & + & $8.13^{\mathrm{b}}$ & $6.32^{\mathrm{bc}}$ & 0.98 & 4.80 & 0.42 & 0.10 & 0.14 & 0.11 \\
\hline \multirow[t]{2}{*}{ Cassava chips } & - & $9.80^{\mathrm{ab}}$ & $6.70^{\mathrm{ab}}$ & 0.99 & 5.10 & 0.47 & 0.11 & 0.13 & 0.08 \\
\hline & + & $8.91^{\mathrm{ab}}$ & $7.71^{\mathrm{a}}$ & 1.05 & 4.71 & 0.44 & 0.09 & 0.17 & 0.10 \\
\hline \multirow[t]{2}{*}{ Cassava pellets } & - & $10.50^{\mathrm{a}}$ & $5.51^{\mathrm{c}}$ & 0.88 & 4.71 & 0.45 & 0.09 & 0.14 & 0.13 \\
\hline & + & $10.82^{\mathrm{a}}$ & $5.91^{\mathrm{bc}}$ & 1.00 & 4.90 & 0.45 & 0.10 & 0.15 & 0.10 \\
\hline \multicolumn{10}{|l|}{ Effect of ingredient } \\
\hline Maize (control) & & $8.51^{\mathrm{b}}$ & $6.23^{\mathrm{b}}$ & 0.94 & 4.91 & 0.42 & 0.09 & 0.15 & 0.13 \\
\hline Cassava chips & & $9.44^{\mathrm{ab}}$ & $7.22^{\mathrm{a}}$ & 1.02 & 4.90 & 0.46 & 0.10 & 0.15 & 0.09 \\
\hline Cassava pellets & & $10.62^{\mathrm{a}}$ & $5.71^{\mathrm{b}}$ & 0.94 & 4.81 & 0.45 & 0.09 & 0.14 & 0.12 \\
\hline \multicolumn{10}{|l|}{ Effect of enzyme } \\
\hline- & & 9.82 & 6.10 & 0.92 & 4.91 & 0.45 & 0.09 & 0.14 & 0.12 \\
\hline+ & & 9.21 & 6.60 & 1.01 & 4.80 & 0.44 & 0.10 & 0.15 & 0.10 \\
\hline Polled SEM & & 0.28 & 0.18 & 0.03 & 0.12 & 0.01 & 0.00 & 0.01 & 0.02 \\
\hline Model P & & $<0.04$ & $<0.01$ & 0.52 & 0.94 & 0.90 & 0.54 & 0.64 & 0.95 \\
\hline \multicolumn{10}{|l|}{ Source of variation } \\
\hline Ingredient & & $<0.01$ & $<0.01$ & 0.44 & 0.93 & 0.55 & 0.63 & 0.90 & 0.75 \\
\hline Enzyme & & 0.27 & 0.083 & 0.13 & 0.70 & 0.77 & 0.65 & 0.47 & 0.75 \\
\hline Ingredient $\times$ enzyme & & 0.49 & 0.55 & 0.90 & 0.63 & 0.88 & 0.24 & 0.28 & 0.82 \\
\hline
\end{tabular}

SEM, standard error of mean.

${ }^{1}$ Each value represents the mean of 6 replicates for each treatment group. ${ }^{2}$ Visceral organs weight considered with digesta.

${ }^{a, b, c}$ Values with unlike superscripts within each column are significantly different $(\mathrm{p}<0.05)$.

Table 6. Relative weight of visceral organs (g/100 g of body weight) of broiler chickens at 21 days of age given diets based on cassava products with or without microbial enzymes ${ }^{1}$

\begin{tabular}{|c|c|c|c|c|c|c|c|c|}
\hline Treatments & Enzyme & Small intest ${ }^{2}$ & Gizzard $^{2}$ & Provent $^{2}$ & Liver & Pancreas & Spleen & Bursa \\
\hline \multicolumn{9}{|l|}{ Ingredient } \\
\hline \multirow[t]{2}{*}{ Maize (control) } & - & $6.60^{\mathrm{b}}$ & $3.41^{\mathrm{a}}$ & $0.61^{\mathrm{a}}$ & $3.60^{\mathrm{bcd}}$ & $0.38^{\mathrm{a}}$ & 0.11 & 0.10 \\
\hline & + & $5.30^{\mathrm{c}}$ & $4.02^{\mathrm{a}}$ & $0.49^{\mathrm{b}}$ & $3.30^{\mathrm{d}}$ & $0.31^{\mathrm{b}}$ & 0.12 & 0.10 \\
\hline \multirow[t]{2}{*}{ Cassava chips } & - & $6.81^{\mathrm{b}}$ & $3.61^{\mathrm{a}}$ & $0.55^{\mathrm{abc}}$ & $3.41^{\mathrm{cd}}$ & $0.33^{\mathrm{ab}}$ & 0.14 & 0.11 \\
\hline & + & $7.10^{\mathrm{b}}$ & $3.51^{\mathrm{a}}$ & $0.57^{\mathrm{ab}}$ & $4.00^{\mathrm{ab}}$ & $0.39^{\mathrm{a}}$ & 0.13 & 0.12 \\
\hline \multirow[t]{2}{*}{ Cassava pellets } & - & $8.00^{\mathrm{a}}$ & $2.20^{\mathrm{b}}$ & $0.62^{\mathrm{a}}$ & $4.21^{\mathrm{a}}$ & $0.37^{\mathrm{a}}$ & 0.11 & 0.10 \\
\hline & + & $7.31^{\mathrm{ab}}$ & $1.90^{\mathrm{b}}$ & $0.46^{\mathrm{c}}$ & $3.80^{\mathrm{abc}}$ & $0.30^{\mathrm{b}}$ & 0.11 & 0.11 \\
\hline \multicolumn{9}{|l|}{ Effect of ingredient } \\
\hline Maize (control) & & $6.1^{\mathrm{c}}$ & $3.71^{\mathrm{a}}$ & 0.55 & $3.40^{\mathrm{b}}$ & 0.34 & 0.12 & 0.10 \\
\hline Cassava chips & & $6.9^{\mathrm{b}}$ & $3.52^{\mathrm{a}}$ & 0.56 & $3.10^{\mathrm{ab}}$ & 0.36 & 0.13 & 0.12 \\
\hline Cassava pellets & & $7.6^{\mathrm{a}}$ & $2.10^{\mathrm{b}}$ & 0.54 & $4.11^{\mathrm{a}}$ & 0.33 & 0.11 & 0.10 \\
\hline \multicolumn{9}{|l|}{ Effect of enzyme } \\
\hline- & & $7.1^{\mathrm{a}}$ & 3.01 & $0.59^{\mathrm{a}}$ & 3.71 & 0.36 & 0.12 & 0.10 \\
\hline+ & & $6.6^{\mathrm{b}}$ & 3.10 & $0.51^{\mathrm{b}}$ & 3.60 & 0.33 & 0.12 & 0.11 \\
\hline Polled SEM & & 0.18 & 0.16 & 0.02 & 0.08 & 0.01 & 0.01 & 0.01 \\
\hline Model P & & $<0.01$ & $<0.01$ & $<0.01$ & $<0.01$ & $<0.01$ & 0.84 & 0.99 \\
\hline \multicolumn{9}{|l|}{ Source of variation } \\
\hline Ingredient & & $<0.01$ & $<0.01$ & 0.84 & $<0.01$ & 0.53 & 0.46 & 0.90 \\
\hline Enzyme & & $<0.023$ & 0.64 & $<0.01$ & 0.72 & 0.07 & 0.85 & 0.88 \\
\hline Ingredient $\times$ enzyme & & $<0.037$ & 0.30 & $<0.03$ & $<0.01$ & $<0.01$ & 0.81 & 0.99 \\
\hline
\end{tabular}

SEM, standard error of mean.

${ }^{1}$ Each value represents the mean of 6 replicates for each treatment group. ${ }^{2}$ Visceral organs weight considered with digesta.

${ }^{a, b, c, d}$ Values with unlike superscripts within each column are significantly different $(\mathrm{p}<0.05)$. 
Table 7. ME intake, net energy production (NEp), heat production (HP), energy retained and efficiencies of ME use for energy, lipid and protein retention in broiler chicks on the different diets to 21 days ${ }^{1}$

\begin{tabular}{|c|c|c|c|c|c|c|c|c|c|}
\hline \multirow[t]{2}{*}{ Treatments } & \multirow[t]{2}{*}{ Enzyme } & \multirow{2}{*}{$\begin{array}{l}\text { ME intake } \\
(\mathrm{kj} / \mathrm{d})\end{array}$} & \multicolumn{2}{|c|}{ Energy utilization $(\mathrm{kJ} / \mathrm{d})$} & \multicolumn{2}{|c|}{ Energy retained $(\mathrm{kJ} / \mathrm{d})$ as } & \multicolumn{3}{|c|}{$\begin{array}{l}\text { Efficiencies of ME use for energy, lipid } \\
\text { and protein retention }\end{array}$} \\
\hline & & & NEp & HP & Protein & Fat & Energy & Lipid & Protein \\
\hline \multicolumn{10}{|l|}{ Ingredient } \\
\hline \multirow[t]{2}{*}{ Maize (control) } & - & $557.9^{\mathrm{c}}$ & $253.6^{\mathrm{b}}$ & $304.3^{\mathrm{d}}$ & $96.0^{\mathrm{ab}}$ & $130.5^{\mathrm{b}}$ & $0.45^{\mathrm{a}}$ & $0.23^{\mathrm{a}}$ & $0.17^{\mathrm{a}}$ \\
\hline & + & $704.8^{\mathrm{a}}$ & $326.6^{\mathrm{a}}$ & $378.2^{\mathrm{ab}}$ & $108.3^{\mathrm{a}}$ & $166.6^{\mathrm{a}}$ & $0.46^{\mathrm{a}}$ & $0.24^{\mathrm{a}}$ & $0.15^{\mathrm{ab}}$ \\
\hline \multirow[t]{2}{*}{ Cassava chips } & - & $465.4^{\mathrm{d}}$ & $157.1^{\mathrm{d}}$ & $308.3^{\mathrm{d}}$ & $52.4^{\mathrm{d}}$ & $75.3^{\mathrm{e}}$ & $0.34^{\mathrm{c}}$ & $0.16^{\mathrm{c}}$ & $0.11^{\mathrm{c}}$ \\
\hline & + & $549.3^{\mathrm{c}}$ & $197.0^{\mathrm{c}}$ & $352.3^{\mathrm{c}}$ & $68.3^{\mathrm{c}}$ & $100.2^{\mathrm{d}}$ & $0.36^{\mathrm{bc}}$ & $0.18^{\mathrm{bc}}$ & $0.12^{\mathrm{c}}$ \\
\hline \multirow[t]{2}{*}{ Cassava pellets } & - & $587.9^{\mathrm{c}}$ & $216.1^{\mathrm{c}}$ & $371.8^{\mathrm{bc}}$ & $87.9^{\mathrm{b}}$ & $107.5^{\mathrm{cd}}$ & $0.37^{\mathrm{bc}}$ & $0.18^{\mathrm{bc}}$ & $0.15^{\mathrm{ab}}$ \\
\hline & + & $649.6^{\mathrm{b}}$ & $256.9^{\mathrm{b}}$ & $396.8^{\mathrm{a}}$ & $111.2^{\mathrm{a}}$ & $126.0^{\mathrm{bc}}$ & $0.39^{\mathrm{b}}$ & $0.19^{\mathrm{b}}$ & $0.17^{\mathrm{a}}$ \\
\hline \multicolumn{10}{|l|}{ Effect of ingredient } \\
\hline Maize (control) & & $631.4^{\mathrm{a}}$ & $290.1^{\mathrm{a}}$ & $341.3^{\mathrm{b}}$ & $102.1^{\mathrm{a}}$ & $148.6^{\mathrm{a}}$ & $0.46^{\mathrm{a}}$ & $0.23^{\mathrm{a}}$ & $0.16^{\mathrm{a}}$ \\
\hline Cassava chips & & $507.4^{\mathrm{b}}$ & $177.1^{\mathrm{c}}$ & $330.3^{\mathrm{b}}$ & $60.4^{\mathrm{b}}$ & $87.8^{\mathrm{c}}$ & $0.35^{\mathrm{c}}$ & $0.17^{\mathrm{b}}$ & $0.12^{\mathrm{b}}$ \\
\hline Cassava pellets & & $618.7^{\mathrm{a}}$ & $236.5^{\mathrm{b}}$ & $384.3^{\mathrm{a}}$ & $99.6^{\mathrm{a}}$ & $116.7^{\mathrm{b}}$ & $0.38^{\mathrm{b}}$ & $0.19^{\mathrm{b}}$ & $0.16^{\mathrm{a}}$ \\
\hline \multicolumn{10}{|l|}{ Effect of enzyme } \\
\hline- & & $537.1^{\mathrm{b}}$ & $208.9^{\mathrm{b}}$ & $328.2^{\mathrm{b}}$ & $78.8^{\mathrm{b}}$ & $104.5^{\mathrm{b}}$ & 0.39 & 0.19 & 0.14 \\
\hline+ & & $634.6^{\mathrm{a}}$ & $260.2^{\mathrm{a}}$ & $375.8^{\mathrm{a}}$ & $96.0^{\mathrm{a}}$ & $131.0^{\mathrm{a}}$ & 0.40 & 0.20 & 0.15 \\
\hline Pooled SEM & & 13.92 & 9.93 & 6.55 & 4.07 & 5.58 & 0.01 & 0.01 & 0.01 \\
\hline Model P & & $<0.01$ & $<0.01$ & $<0.01$ & $<0.01$ & $<0.01$ & $<0.01$ & $<0.01$ & $<0.01$ \\
\hline \multicolumn{10}{|l|}{ Source of variation } \\
\hline Ingredient & & $<0.001$ & $<0.001$ & $<0.001$ & $<0.001$ & $<0.001$ & $<0.001$ & $<0.001$ & $<0.001$ \\
\hline Enzyme & & $<0.001$ & $<0.001$ & $<0.001$ & $<0.001$ & $<0.001$ & 0.081 & 0.14 & 0.39 \\
\hline Ingredient $\times$ enzyme & & $<0.013$ & 0.25 & $<0.011$ & 0.56 & 0.51 & 0.79 & 0.59 & $<0.020$ \\
\hline
\end{tabular}

ME, metabolizable energy; SEM, standard error of mean.

${ }^{1}$ Each value represents the mean of 6 replicates for each treatment group.

a,b,c,d,e Values with unlike superscripts within each column are significantly different $(\mathrm{p}<0.05)$.

\section{Metabolizable energy intake and utilization}

Metabolizable energy intake was reduced $(\mathrm{p}<0.001)$ in birds fed both cassava chips and pellets without enzyme supplementation but was increased $(p<0.001)$ in all the diets with enzyme supplementation (Table 7). A similar trend was observed for NEp, generally being higher $(p<0.01)$ on the maize-based diets than on diets containing cassava, and enzyme supplementation improving $(p<0.01)$ NEp in all diets. The highest estimated HP was observed in birds fed diets containing cassava pellets and it increased $(\mathrm{p}<0.01)$ by enzyme supplementation in all diets. More energy was retained as protein and fat in birds fed the maize-based diets than diets containing cassava products $(p<0.01)$ and this was increased $(p<0.01)$ in all diets as a result of enzyme supplementation. The efficiencies of utilization of ME for energy and lipid retention were reduced $(p<0.01)$ with the inclusion of cassava products compared to the maize diet, but these were unaffected by enzyme supplementation, within diet.

\section{Digestibility of nutrients}

At 21 days of age, the ileal digestibility of protein, GE and starch was not significantly affected by diet and enzyme supplementation (Table 8). In general, protein, energy and starch digestibility tended to increase in diets
Table 8. Digestibility coefficients of crude protein, gross energy and starch at 21 days of age given diets based on cassava products with or without microbial enzymes

\begin{tabular}{lcccc}
\hline Treatments & Enzyme & $\begin{array}{c}\text { Crude } \\
\text { protein }\end{array}$ & $\begin{array}{c}\text { Gross } \\
\text { energy }\end{array}$ & Starch \\
\hline Ingredient & & & & \\
$\quad$ Maize (control) & - & 0.72 & 0.76 & 0.91 \\
& + & 0.68 & 0.73 & 0.96 \\
Cassava chips & - & 0.67 & 0.71 & 0.94 \\
& + & 0.69 & 0.75 & 0.94 \\
Cassava pellets & - & 0.65 & 0.71 & 0.96 \\
& + & 0.68 & 0.72 & 0.97 \\
Effect of ingredient & & & & \\
Maize (control) & & 0.70 & 0.74 & 0.94 \\
Cassava chips & & 0.68 & 0.73 & 0.94 \\
Cassava pellets & & 0.66 & 0.71 & 0.97 \\
Effect of enzyme & & & & \\
$\quad-$ & & 0.67 & 0.72 & 0.94 \\
$\quad+$ & & 0.68 & 0.73 & 0.96 \\
Polled SEM & & 0.028 & 0.026 & 0.009 \\
$\quad$ Model P & & 0.094 & 0.080 & 1.01 \\
Source of variation & & & & \\
Ingredient & & 0.91 & 0.91 & 0.35 \\
Enzyme & & 0.99 & 0.91 & 0.26 \\
Ingredient $\times$ enzyme & 0.88 & 0.91 & 0.47 \\
\hline
\end{tabular}

SEM, standard error of mean. 
when supplemented with the microbial enzymes.

\section{DISCUSSION}

\section{Growth performance of broiler chickens}

The primary aim of the present study was to evaluate two cassava products, chips and pellets, as replacement for maize, with or without enzyme supplementation, in broiler chicken diets. The nutrients in cassava chips and pellets were apparently used less efficiently for growth than nutrients in maize. Overall, gross response on the cassavabased products was inferior to that on the maize-based diets. Generally cassava starch is more digestible than maize starch, the former being higher in amylopectin (Gomes et al., 2005). However, cassava is lower in protein and diets may require supplementation with synthetic amino acids to meet the growth requirement of poultry.

The pellets performed better than chips in terms of FI, BW and FCR. This is in agreement with Burn et al. (1990), who reported that up to $66.7 \%$ of maize in broiler diets can be replaced by cassava meal without adversely affecting growth performance of broilers. Addition of these microbial enzymes to diets increased overall productivity such as FI, BW gain and FCR on the maize (control), cassava pellets and cassava chips diets. This is in agreement with the results of Akinfala et al. (2009), who observed a beneficial effect of feed additives, including baker's yeast, as well as enzymes (hemicellulases) in cassava-based diets fed to broiler chickens. Similarly, Acamovic (2001) suggested that the utilization of cassava in broiler diets can be enhanced with enzyme supplementation, as is commonly found with cereal grains. In the current study, the FI was reduced when birds were fed-high fibre cassava-based diets without supplementation of enzymes. This could be due to the inability of the birds to digest the fibre, which would then create a gut fill sensation and subsequent depression of appetite. High levels of fibre also reduce the transit time of food through the digestive system (Connell, 1981). Additionally, a reduction of growth due to a lower density of digestible nutrients in cassava products compared to maize may be related to the reduction on FI.

In a previous study by Obikaonu and Udedibie (2006), birds fed on a diet based on cassava ensiled peel meal had similar FI and BW gain compared to a control group, whereas the FCR of birds on sun-dried cassava peel meal was poor. Microbial digestion of fibre occurs during ensiling, similar to the effect of microbial enzymes in the diet. However, the digestibility of starch was not significantly improved due to microbial enzyme supplementation of the diets based on cassava pellets or chips.

In this study, the relative weight of visceral organ, in particular small intestine, gizzard, proventriculus, liver and pancreas were increased in chicks on both cassava chips and cassava pellet diets at both ages, day 7 and 21 . This is in partial agreement with the result of Borin et al. (2006), who reported that the weight of above mentioned organs increased with an increase in cassava leaf meal. Cassava leaves tend to be higher in fibre than root meals and root chips are less processed than pellets, and may contain fibre in relatively large quantity.

\section{Energy utilization of broiler chickens}

In this study, the ME content of the experimental diets were similar, but ME intake was reduced on diets containing cassava chips or pellets, which may be due to high fibre contents of the two diets when compared to maize. However, ME intake was increased in all diets when supplemented with microbial enzymes. This agrees with results by Iji et al. (2011), who reported that NEp and HP were reduced by cassava pulp but were increased by enzyme supplements similar to those used in the present study.

The benefit of enzymes was likely related to an increase in the rate of nutrient digestibility and changes on the ability of the bird to adapt to higher fibre levels. Phytic acid, in particular can adversely affect energy utilization and the availability of other nutrients in poultry diets (Ravindran et al., 2005). Besides, increased activity of gut microflora on the dietary factors can lead to energy wastage (Choct et al., 1996) or availability as well as digestibility of other nutrients (Smits et al., 1997). Le Goff and Noblet (2001) also reported that most of the variation in digestibility of feed energy is related to the presence of dietary fibre.

In the current study, broilers on the maize-based control diets showed higher NEp, with high HP when supplemented with microbial enzymes. This group of birds also attained heavier BW than those on cassava-based diets. This improvement in NEp and performance of birds is evidence of more efficient utilization of energy on these diets due to improvement in nutrient and energy availability (Olukosi et al., 2008).

Heat production of birds varied significantly between treatments and was higher the on maize-based control and cassava pellets diets than on the cassava chips only when supplemented with enzymes. This increase in HP on the former two diets may be due to higher FI, in particular protein intake (Johnson, 2007). The maize-based control diets also resulted in increased efficiencies of ME use for energy, lipid and protein retention, which is supported by the findings of Boekholt et al. (1994) who reported that when protein is not limiting in the diets of broilers, extra energy available in the diets is used for both fat and protein accumulation. Conversely, the rate of deposition of energy 
and fat was reduced in birds on the cassava chips diets but protein deposition was higher on cassava pellets diets.

In general, more energy was retained as lipid than protein on the maize-based control diet, which may be due to differences in the energy to protein ratios between maize and cassava products-based diets. Lesson and Summers (1997) have reported that abdominal fat of birds increases with age whereas protein accretion decreases. This is related to the maturity of birds and is found commonly in most strains (Lesson, 1995). In the current study, the proportion of the retention of lipid was found to be higher than that of protein as birds in the test age group (0 to $21 \mathrm{~d}$ ) are still in the actively growing phase of production (Bregendhl et al., 2002). The efficiency of utilization of ME for energy, protein and fat retention was affected by dietary treatment, the ME being more efficiently used for energy deposition and less for protein and fat disposition. It is unclear what this implies but such energy may be deposited as fat as the birds becomes older. On a technical note, some of our values of HP and NEp do not exactly add to ME intake. This deviation was around $5 \%$ and may be due to minor over-estimation of energy intake or discrepancy in bomb calorimetry. Overall, this error would not greatly alter the results.

This study suggests that cassava pellets or chips could be used to replace maize in broiler diets at up to $50 \%$, with enzyme supplementation of such diets. This was supported by the fact that the cassava products had no adverse effects on carcass weight, abdominal fat and carcass composition. However, the commercial use of the products would depend on price, and the cost of protein sources, synthetic amino acids and pigments. The diets would need to be supplemented with appropriate microbial enzymes.

\section{ACKNOWLEDGMENTS}

The cassava products and enzymes were supplied by Feedworks Aus. Pty. Ltd.

The work was supported by the DuPont (formerly Danisco Animal Nutrition Ltd), UK.

\section{REFERENCES}

Acamovic, T. 2001. Commercial application of enzyme technology for poultry production. World's Poult. Sci. J. 57:226-242.

Akinfala, E. O., O. Matanmi, A. A. Fatufe, and J. A. Tinuala. 2009. Supplemental effects of feed additives on the utilization of cassava plant meal by broiler chicken. Bull. Anim. Health Prod. Africa. 57:269-276.

Anderson, D. L. and L. J. Henderson. 1986. Sealed chamber digestion for plant nutrient analyses. Agron. J. 78:937-938.

Bedford, M. R. 1995. Mechanism of action and potential environmental benefits from the use of feed enzymes. Anim.
Feed Sci. Technol. 53:145-155.

Bedford, M. R. 2001. Enzymes, antibiotics and intestinal micro flora. Feed Mix, 9:(2)2001.

Beokholt, H. A., P. H. Van Der Grinten, V. V. A. M. Scheurs, M. J. N. Los, and C. P. Leffering. 1994. Effect of dietary energy restriction on retention of protein, fat and energy in broiler chickens. Br. Poult. Sci. 35:603-614.

Borin, K., J. E. Lindberg, and R. B. Ogle. 2006. Digestibility and digestive organ development in indigenous and improved chickens and ducks fed diets with increasing inclusion levels of cassava leaf meal. J. Anim. Physiol. Anim. Nutr. 90:230-237.

Bregendahl, K., J. L. Sell, and D. R. Zimmerman. 2002. Effect of low-protein diets on growth performance and body composition of broiler chicks. Poult. Sci. 81:1156-1167.

Brum, P. A. R. D., A. L. Guidoni, L. F. T. Albino, and J. S. Cesar. 1990. Whole cassava meal in diest for broiler chickens. Pesquisa Agropecuaria Brasileira 25:1367-1373.

Carpenter, K. J. and K. M. Clegg. 1956. The metabolizable energy of poultry feeding stuffs in relation to their chemical composition. J. Sci. Food Agric. 7:45-51.

Choct, M., R. J. Hughes, J. Wang, M. R. Bedford, A. J. Morgan, and G. Annison. 1996. Increased small intestinal fermentation is partly respsonsible for the anti-nutritive activity of nonstarch polysaccharids in chickens. Br. Poult. Sci. 37:609-621.

Chrastil, J. 1987. Improved colorimetric determination of amylose in starches or flours. Charbohydr. Res. 159:154-158.

Cohen, S. A. 2001. Amino acid analysis using precolumn derivatisation with 6-aminoquinolyl-N-hydroxysuccinimidyl carbamate. In: Molecular Biology (Vol. 159) (Eds. C. Cooper, N. Packer, and K. Williams). Humana Press, Totowa, NJ, USA.

Cohen, S. A. and D. P. Michaud. 1993. Synthesis of a fluorescent derivatizing reagent, 6-aminoquinolyl-N-hydroxysuccinimidyl carbamate, and its application for the analysis of hydrolysate amino acids via high-performance liquid chromatography. Anal. Biochem. 211:279-287.

Connell, A. M. 1981. Dietry fibre. In: Physiology of Gastrointestinal Tract (Ed. L. R. Johnson). Raven Press, New York, NY. Pp. 1291-1299.

Cowieson, A. J., D. N. Singh, and O. Adeola. 2006. Prediction of ingredient quality and the effect of a combination of xylanase, amylase, protease and phytase in the diets of broiler chicks. 1 . Growth performance and digestible nutrient intake. Br. Poult. Sci. 47:477-489.

Englyst, H. N. and G. J. Hudson. 1993. Dietary fiber and starch: Classification and measurement. In: Dietary Fiber and Human Nutrition, 2nd ed., (Eds. G. A. Spiller). CRC Press, Ins., Boca Raton, FL, USA. pp. 53-71.

FAO 2012. FAOSTAT, http://faostat3.fao.org/home/index.html\# DOWNLOAD http://faostat3.fao.org/faostat-gateway/go/to/ download/Q/QC/E Assessed 24 Mar.2014

Gibson, T. S., V. A. Solah, and B. V. McCleary. 1997. A procedure to measure amylose in cereal starches and flours with Concanavalin A. J. Cereal Sci. 25:111-119.

Gomes, E., S. R. Souza, R. P. Grandi, and R. D. Silva. 2005. Production of thermostable glucoamylase by newly isolated Aspergillus Flavus A 1.1 and thermomyces Lanuginosus A 13.37. Braz. J. Microbiol. 36:75-82.

Iji, P. A., M. M. Bhuiyan, N. Chauynarong, M. R. Barekatain, and 
A. P. Widodo. 2011. Improving the nutritive value of alternative feed ingredients for poultry. Proceedings of the Recent Advanced in Animal Nutrition, Australia. 18:115-122.

Johnson, D. E. 2007. Contribution of animal nutrition research to nutritional principles: Energetics. J. Nutr. 137:698-701.

Larbier, M. and B. Leclercq. 1992. Energy metabolism. In: Nutrition and Feeding of Poultry (Ed. J. Wiseman). Nottingham University Press, Nottingham, UK. pp. 47-73.

Le Goff, G. and J. Noblet. 2001. Comparative total tract digestibility of dietary energy and nutrients in growing pigs and adult sows. J. Anim. Sci. 79:2418-2427.

Lesson, S. and J. D. Summers. 1997. Feeding programs for broilers. In Commercial Poultry Nutrition, 2nd ed. University Books, University of Guelph, Guelph, ON, Canada. 207-254.

Lesson, S. 1995. New concepts in feeding broiler. XIV Congreso Latinoamericano de Avicultura, Chile. pp. 30-40.

Mccleary, B. V., V. Solah, and T. S. Gibson. 1994. Quantitative measurement of total starch in cereal flours and products. J. Cereal Sci. 20:51-58.

NRC. 1994. Nutrient Requirements of Poultry, 9th Revised Edition, National Research Council. National Academy Press, Washington, DC, USA.

Obikaonu, H. O. and A. B. I. Udedibie. 2006. Comparative evaluation of sud-dried and ensiled cassava peel meals as substitute for maize in broielr diests. Inter. J. Agric. Rural Dev. 7:52-55.
Olukosi, O. A., A. J. Cowieson, and O. Adeola. 2008. Energy utilization and growth performance of broilers receiving diets supplemented with enzymes containing carbohydrase or phytase activity individually or in combination. Br. J. Nutr. 99: 682-690.

Ravindran, V., J. S. Sands, M. Hruby, and G. G. Partridge. 2005. Influence of phyzyme XP phytase on nutrient utilization in broilers fed diets containing graded levels of phytate. Proceedings of the Australian Poultry Science Symposium. University of Sydney, Sydney, NSW, Australia. 17:238-241.

Short, F. J., P. Gorton, J. Wiseman, and K. N. Boorman. 1996. Determination of titanium dioxide added as an inert marker in chicken digestibility studies. Anim. Feed Sci. Technol. 59:215221

Smits, C. H., A. Veldman, M. W. A. Verstegen, and A. C. Beynen. 1997. Dietary carboxymethylcellulose with instead of low viscosity reduces macronutrient digestion in broiler chickens. J. Nutr. 127:483-487.

SPSS Inc. 2010. Version 18.0.0. SPSS Inc., Chicago, IL, USA.

Sweeney, R. A. 1989. Generic combustion method for determination of crude protein in feeds: Collaborative study. J. Assoc. Off. Anal. Chem. 72:770-774.

Theander, O. and E. Westerlund. 1993. Determination of individual components of dietary fiber. In: Dietary Fiber and Human Nutrition, 2nd Ed., (Ed. G. A. Spiller). CRC Press Inc. Boca Raton, FL, USA. pp. 77-98. 